\title{
IN VITRO CELLULASE PRODUCTION FROM FIVE HERBIVORE MICROBIAL ECOSYSTEMS AND CONSORTIA*
}

\author{
Fabian Nde Fon ${ }^{1 \star}$, Ignatius Verla Nsahlai ${ }^{2}$, Peter Frank Scogings ${ }^{1}$, \\ Nasreldin Abdelrahim Dafaalla Basha ${ }^{2,3}$
}

\author{
${ }^{1}$ Department of Agriculture, University of Zululand, KwaDlangezwa, Empangeni, 3886, South Africa \\ ${ }^{2}$ Animal and Poultry Science, University of KwaZulu-Natal, Pietermaritzburg Campus, Durban Road, \\ Pietermaritzburg, 3201, South Africa \\ ${ }^{3}$ Department of Animal Nutrition, Shampat Campus, University of Khartoum, P.O.Box 32, \\ Postal Code 1334, Sudan \\ •Corresponding author: fabiannde@yahoo.co.uk
}

\begin{abstract}
As the most abundant biomass in nature, cellulose is the main chemical component in herbivore forages. The energy locked in these complex polymers can only be released by cellulolytic enzymes. Therefore, research aiming to increase the expression of cellulolytic enzymes or browsing uncultured microbial ecosystem in search of potential fibrolytic enzymes is imperative. The main objectives were to: (a) investigate the variation of cellulase enzymes in cow $(\mathrm{CW})$, horse $(\mathrm{H})$, miniature horse $(\mathrm{mH})$, wildebeest $(\mathrm{WB})$ and zebra $(\mathrm{ZB})$; and $(\mathrm{b})$ identify their presence and activeness in microbial consortia, $\mathrm{N} 1(\mathrm{H}+\mathrm{WB}), \mathrm{N} 2(\mathrm{H}+\mathrm{ZB}), \mathrm{N} 3(\mathrm{WB}+\mathrm{ZB})$ and $\mathrm{N} 4(\mathrm{H}+\mathrm{WB}+\mathrm{ZB})$. Fresh faecal or rumen inocula were cultured in the laboratory on maize stover and lucerne $(1: 1)$ with salivary buffer for $72 \mathrm{~h}$ at $38^{\circ} \mathrm{C}$. Crude proteins (CPZ) were precipitated from both fresh and cultured inocula using $\mathbf{6 0 \%}$ ammonium sulfate for enzyme assays and zymography. Endocellulases and their activity were identified on $1 \%(\mathrm{~m} / \mathrm{v})$ carboxymethyl cellulose (CMC) zymograms stained with Congo red. All CPZ extracts were active as reducing sugars were produced after incubation with crystalline cellulose, $\mathrm{CMC}$ and xylan. The number and types of proteins with endocellulase activity

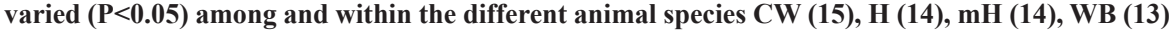
and ZB (13). Microbial consortia were active with relatively higher number of endocellulases, N1 (17), N3 (14), N4 (14), and N2 (13). Cellulase enzymes vary among and within herbivore species grazing on the same or different fields. Therefore, identifying specific enzymes and microbes with higher fibrolytic potentials from different ecosystems for transinoculation could play a vital role in improving forage digestibility in ruminants.
\end{abstract}

Key words: fibrolytic enzymes, rumen, faecal inoculum

\footnotetext{
* Research financed by the National Research Foundation, South Africa.
} 
Cellulose is a plant polysaccharide composed of $\beta$-D-glucopyranosyl units joined together by $\beta$-1, 4-glycosidic bonds. It is the major component of plant cell walls and most abundant plant polysaccharide. The breakdown of cellulose to glucose units occurs in three basic steps involving three major cellulase enzymes, namely exocellulase, endocellulase and cellobiase (Percival Zhang et al., 2006); (1) endocellulase randomly hydrolyzes $\beta-1,4$ glycosidic linkages in the amorphous regions of the cellulose chains, (2) exocellulase hydrolyzes $\beta-1,4$ glucocidyl linkages at either the non-reducing or reducing ends of cellulose forming cellobiose and (3) $\beta$-cellobiase hydrolyzes cellobiose into two glucose molecules. These glucose molecules are fermented by the anaerobic microbes for energy generation (ATP) yielding short chain fatty acids (SCFA) as by-products which are the main metabolic substrates for energy production in ruminants.

Cellulases and related enzymes are commonly used in many industrial applications including food, brewery, paper, animal feed and agricultural research (Beauchemin et al., 2003). Animal feed will be the main focus as more than 600 million tonnes of feed worth more than 50 billion US dollars are produced annually (Bhat, 2000). Cellulases and xylanases have been shown to have a wide range of feasible applications in both monogastric and ruminant animals (Yang and Xie, 2010). In monogastric animals, cellulases are used either to eliminate anti-nutritional factors present in grains or vegetables, degrade certain cereal components in order to improve the nutritional value of feed or to supplement animals' own digestive enzymes whenever these enzymes are insufficient, especially in the post-weaning period in piglets (Bhat, 2000). In ruminants, it has been used to improve feed digestibility, milk yield, body weight gains and animal performance (Arriola et al., 2011). Although many studies on enzyme supplementation have shown substantial improvements in feed digestibility and animal performance (Bala et al., 2009; Titi and Tabbaa, 2004), others reported negative effects or none at all (O’Connor-Robison et al., 2007; Peters et al., 2010).

Enzyme sources can be either pure or crude (but richer in the application enzyme). Pure cellulase enzymes are expressed by specific microorganisms using molecular biology techniques in the laboratory while crude cellulase enzyme mixtures are concentrated from in vitro incubators. Although cellulase expressions by microbes or genetically modified microbes have been the main sources of enzymes, attempts have also been made to clone cellulase and xylanase genes in order to produce transgenic animals (Hall et al., 1993). These animals would secrete the required enzymes into the gastrointestinal tract to facilitate its feed digestion efficiency. Research of this sort is not very common though it has the potential of unveiling more information on cellulase functions. Despite many reports describing the isolation and characterization of cellulases and xylanase from different environmental genomic libraries, the biotechnological potential of novel cellulases from uncultured microbial community is far from being fully explored. Therefore, exploring a variety of ecosystems to identify the different types (size) of cellulase enzymes present, their fibrolytic potential as well as their combined effect might be beneficial in ruminant nutrition.

The main objectives were: (a) to identify the types of cellulase enzymes available in the following individual microbial ecosystems (IS): cow (CW), horse (H), miniature horse $(\mathrm{mH})$, wildebeest $(\mathrm{WB})$ and zebra $(\mathrm{ZB})$; and (b) identify their pres- 
ence and activeness in consortia (to investigate combined effect), N1 (H+WB), N2 $(\mathrm{H}+\mathrm{ZB}), \mathrm{N} 3(\mathrm{WB}+\mathrm{ZB})$ and N4 $(\mathrm{H}+\mathrm{WB}+\mathrm{ZB})$.

\section{Material and methods}

Samples (faeces) were collected randomly in winter from four animals: horses $(\mathrm{H})$ and miniature horses $(\mathrm{mH})$ (Ukulinga Research farm, University of KwaZulu Natal), blue wildebeests (WB) and plains zebras (ZB) with no preference to sex. Equus quagga (ZB) and Connochaetes taurinus (WB) were available at the Tala Game Reserve, uMbumbulu. The ZB and WB were grazing on a dry land in an open field where Pennisetum clandestinum (Kikuyu grass) was dominant among other dry grasses. Rumen fluid was collected from the cows (CW) alone. Although the $\mathrm{CW}, \mathrm{mH}$ and $\mathrm{H}$ were grazing on a dry land in an open field where Kikuyu grass was dominant, they were supplemented with veld hay while in pens.

Faeces were collected within 2 min of defecation from $\mathrm{mH}, \mathrm{H}, \mathrm{ZB}$ and $\mathrm{WB}$ before transferring into an airtight insulated flask $\left(38^{\circ} \mathrm{C}\right)$ which had been flushed with $\mathrm{CO}_{2}$. While in the laboratory, $300 \mathrm{~g}$ of faeces was mixed with $300 \mathrm{ml}$ of warm incubation buffer (made by titrating 21 of warmed solution A (solution $\mathrm{A}, \mathrm{NaHCO}_{3}$ (19.60 g), $\mathrm{Na}_{2} \mathrm{HPO}_{4}(7.40 \mathrm{~g}), \mathrm{KCl}$ (1.14 g), NaCl (0.94 g), $\mathrm{MgCl} .6 \mathrm{H}_{2} \mathrm{O}$ (0.26 g) and (NH4) $)_{2} \mathrm{SO}_{4}(5.8 \mathrm{~g})$, in 21 distilled water) with $2 \mathrm{ml}$ of Solution $\mathrm{B}\left(53 \mathrm{~g} \mathrm{CaCl}_{2} \cdot 2 \mathrm{H}_{2} \mathrm{O}\right.$ in 11 distilled water) and flushed with $\mathrm{CO}_{2}$ (Tilley and Terry, 1963). The mixture was stirred thoroughly before squeezing through four layers of cheese cloth (prewarmed and flushed with $\mathrm{CO}_{2}$ ) to make faecal fluid (FF). For the cow, rumen fluid $(200 \mathrm{ml})$ was collected through a fistula, strained through cheese cloth (pre-warmed and flushed with $\mathrm{CO}_{2}$ ) to make rumen fluid (RF). All inocula were prepared in the shortest possible time in order to minimize the exposure of anaerobic microbes to oxygen. For each animal species, two samples were collected and pulled together to represent that species before sampling.

For rumen or faecal fluid culturing, $198 \mathrm{ml}$ of each filtrate $(\mathrm{CW}, \mathrm{mH}, \mathrm{H}, \mathrm{WB}$ or ZB) was pipetted into $402 \mathrm{ml}$ of incubation buffer (flushed with $\mathrm{CO}_{2}$ and placed in an incubator to equilibrate to $39^{\circ} \mathrm{C}$ for $1 \mathrm{~h}$ ) containing $6 \mathrm{~g}$ of $1: 1$ mixture of lucerne (LS) and maize stover (MS) milled through a 1-mm sieve. For microbial consortia, $\mathrm{N} 1(\mathrm{H}+\mathrm{WB}), \mathrm{N} 2(\mathrm{H}+\mathrm{ZB}), \mathrm{N} 3(\mathrm{WB}+\mathrm{ZB})$ and $\mathrm{N} 4(\mathrm{H}+\mathrm{WB}+\mathrm{ZB})$ were mixed in equal proportions to investigate microbial synergism. The culture samples were flushed with $\mathrm{CO}_{2}$ and incubated for $72 \mathrm{~h}$ at $38.5^{\circ} \mathrm{C}$ in airtight Duran ${ }^{\circledR}$ bottles (Duran Group, Germany) (4 L). After $72 \mathrm{~h}$, cultured RF or FF was used for extraction of crude protein (CPZ) for enzyme assays and zymography. After culturing, $\mathrm{CW}, \mathrm{mH}, \mathrm{H}, \mathrm{WB}$ and ZB became CW1, $\mathrm{mH} 1, \mathrm{H} 1, \mathrm{WB} 1$ and $\mathrm{ZB1}$, respectively.

Crude protein was extracted from cultured filtrate using 60\% $\left(\mathrm{NH}_{4}\right)_{2} \mathrm{SO}_{4}$, dialyzed, concentrated using polyethylene glycol 20000 (Fluka, USA, product no 81298) and concentration determined by Bradford assay. Enzyme assays were carried out to confirm the activeness of each CPZ prior to zymography. Exocellulase was assayed by pipetting $0.5 \mathrm{ml}$ of $1 \%(\mathrm{~m} / \mathrm{v})$ crystalline cellulose (product no 11363 , 
Sigma-Aldrich ${ }^{\circledR}$, Germany) with the reaction buffer (20 mM sodium acetate, $0.02 \%$ $(\mathrm{m} / \mathrm{v}) \mathrm{NaN}_{3}$ and $0.1 \mathrm{mM}$ EDTA at $\left.\mathrm{pH} 5.0\right)$ into $0.5 \mathrm{ml}$ of crude protein solution obtained from rumen fluid or faeces and incubated for $72 \mathrm{~h}$ at $39^{\circ} \mathrm{C}$. The enzyme reaction was stopped by boiling at $100^{\circ} \mathrm{C}$. The reaction mixture for endocellulase assays, contained $0.5 \mathrm{ml}$ of $0.5 \%(\mathrm{~m} / \mathrm{v})$ carboxymethyl cellulose $(\mathrm{CMC})$ from Fluka Biochemica (product no 419273), in the reaction buffer at $\mathrm{pH} 5.5$ and $0.5 \mathrm{ml}$ of CPZ. The enzyme reaction was stopped by boiling at $100^{\circ} \mathrm{C}$ after incubating at $39^{\circ} \mathrm{C}$ for $2 \mathrm{~h}$. Samples were centrifuged at 6000xg at RT for $5 \mathrm{~min}$, then $400 \mu \mathrm{l}$ of the reaction mixture was analysed for reducing sugars. Xylanase activity was assayed by pipetting $0.6 \mathrm{ml}$ of $0.1 \%(\mathrm{~m} / \mathrm{v})$ xylan (Sigma, USA, product no X4252) solution in the reaction buffer ( $\mathrm{pH} 5.0$ ) into $0.4 \mathrm{ml}$ of CPZ solution and incubating at $39^{\circ} \mathrm{C}$ for $1 \mathrm{~h}$. The reaction was stopped with $100 \mu \mathrm{l}$ of $200 \mathrm{mM} \mathrm{NaHCO}_{3}$. All stopped reactions were centrifuged $\left(6000 \mathrm{xg}, 5 \mathrm{~min}\right.$ at $\left.4^{\circ} \mathrm{C}\right)$ and $400 \mu \mathrm{l}$ samples analysed for reducing sugars using 3,5-dinitrosalicylic acid (DNS) method (Miller, 1959), using a spectrophotometer and absorbance read at $540 \mathrm{~nm}$. Reducing sugars in unknown reaction samples were determined on glucose or xylose standard curves as described by Colombatto and Beauchemin (2003). Each enzyme assay was replicated three times with four pseudo repeats. Enzyme specific activity was defined as $\mu \mathrm{g}$ of reducing sugar (glucose or xylose)/mg crude protein.

Both reducing and non-reducing sodium dodecyl sulfate polyacrylamide gel electrophoresis (SDS-PAGE) (Laemmli, 1970) was used in this study to monitor the presence of proteins in the CPZ samples. Crude protein extracts $(10 \mu \mathrm{g} / 5 \mu \mathrm{l})$ were separated on a $10 \%$ running gel. The gels were stained with Coomassie blue- 250 or by silver staining (when the proteins were too small to be stained by Coomassie blue250) for the detection of protein bands on the gel (Blum et al., 1987). Crude protein extracts were run alongside a molecular weight marker $(150,100,75,50,35,25$ and $15 \mathrm{kDa}$ ) (Sigma) for estimating unknown molecular weights of protein bands. Each $\mathrm{CPZ}$ ecosystem extracted at three different times of collection was run on gels more than three times to establish the presence of protein bands.

For zymography assays, CPZ were first separated on a $10 \%$ non-reducing SDS-PAGE gels which had been polymerized with $1 \%(\mathrm{~m} / \mathrm{v}) \mathrm{CMC}$ substrate. After separation, re-naturation of proteins was carried out by soaking the gels in two changes of $50 \mathrm{ml}$ of $2.5 \%(\mathrm{v} / \mathrm{v})$ Triton X-100 (to remove SDS) over $3 \mathrm{~h}$ at room temperature (Dodia et al., 2008; Heussen and Dowdle, 1980). Following this, the gels were incubated in the reaction buffer $\mathrm{pH} 5.0$ at $33^{\circ} \mathrm{C}$ for $48 \mathrm{~h}$. After incubation these gels were stained with $0.2 \%(\mathrm{w} / \mathrm{v})$ Congo red to identify protein bands with cellulase activity as previously described by Beguin (1983). After staining the gels were rinsed with $5 \%$ acetic acid to change the background to blue black for easy photographing. Crude protein extract samples were run alongside a molecular weight marker which was cut off after re-naturation and stained with Coomassie blue-250. These markers were used to plot a standard curve (distances migrated versus molecular weights) to estimate the molecular weight of the unknown active cellulase bands.

In vitro enzyme specific activities estimates derived from $\mathrm{CW}, \mathrm{mH}, \mathrm{H}, \mathrm{WB}, \mathrm{ZB}$, $\mathrm{N} 1, \mathrm{~N} 2, \mathrm{~N} 3$ and N4 were subjected to the analysis of variance (ANOVA) using the general linear model of SAS (2002): 


$$
Y_{i j}=\mu+E_{i}+e_{i j}
$$

where:

$Y-$ is the individual observation,

$\mu-$ is the overall mean,

$E_{i}-$ is the effect of the inoculum source and

$e_{i j}-$ is the random variation.

\section{Results}

Exocellulase, endocellulase and xylanase specific activities were higher $(\mathrm{P}<0.001)$ in the in vitro cultured microbial ecosystems than in the fresh microbial ecosystems (Table 1). For exocellulase enzymes, N1, N2 and N4 had the highest specific activities followed by $\mathrm{H} 1$ with intermediate activity. Endocellulase activity differed $(\mathrm{P}<0.001)$ among the microbial ecosystems with systems N4, H1, ZB1 and N1 recording the highest specific activities. Systems N3, N2, WB1, mH1 and CW were intermediate in their endocellulase specific activities but lower for the fresh microbial ecosystems.

Table 1. Xylanase, endocellulase, and exocellulase specific activities of crude protein extracts

\begin{tabular}{l|r|r|r}
\hline Inoculum source & $\begin{array}{c}\text { Xylanase } \\
(\mu \mathrm{g} \text { xylose } / \mathrm{mg})\end{array}$ & $\begin{array}{c}\text { Endocellulase } \\
(\mu \mathrm{g} \text { glucose } / \mathrm{mg})\end{array}$ & $\begin{array}{c}\text { Exocellulase } \\
(\mu \mathrm{g} \text { glucose } / \mathrm{mg})\end{array}$ \\
\hline $\mathrm{CW}$ & $38.0 \mathrm{e} \pm 2.34$ & $2.9 \mathrm{f} \pm 0.01$ & $1.8 \mathrm{~g} \pm 0.02$ \\
$\mathrm{mH}$ & $30.0 \mathrm{f} \pm 2.14$ & $5.9 \mathrm{e} \pm 0.05$ & $4.5 \mathrm{~g} \pm 0.07$ \\
$\mathrm{H}$ & $46.3 \mathrm{e} \pm 3.11$ & $6.4 \mathrm{e} \pm 1.00$ & $5.4 \mathrm{~g} \pm 0.20$ \\
$\mathrm{WB}$ & $8.0 \mathrm{~g} \pm 2.01$ & $3.7 \mathrm{ef} \pm 0.10$ & $3.2 \mathrm{~g} \pm 0.06$ \\
ZB & $43.5 \mathrm{e} \pm 4.10$ & $5.9 \mathrm{e} \pm 0.14$ & $4.4 \mathrm{~g} \pm 0.30$ \\
$\mathrm{CW} 1$ & $83.2 \mathrm{c} \pm 1.21$ & $78.6 \mathrm{c} \pm 2.11$ & $68.2 \mathrm{f} \pm 3.00$ \\
mH1 & $75.4 \mathrm{c} \pm 1.66$ & $83.3 \mathrm{bc} \pm 3.01$ & $94.9 \mathrm{de} \pm 3.08$ \\
$\mathrm{H} 1$ & $98.3 \mathrm{~b} \pm 1.90$ & $92.7 \mathrm{~b} \pm 2.31$ & $141.8 \mathrm{~b} \pm 9.03$ \\
WB1 & $57.3 \mathrm{e} \pm 5.76$ & $72.6 \mathrm{~d} \pm 0.45$ & $90.5 \mathrm{e} \pm 2.67$ \\
ZB1 & $88.8 \mathrm{bc} \pm 1.53$ & $89.2 \mathrm{~b} \pm 2.11$ & $107.1 \mathrm{c} \pm 0.04$ \\
N1 & $81.4 \mathrm{c} \pm 1.17$ & $87.8 \mathrm{~b} \pm 4.57$ & $163.1 \mathrm{a} \pm 6.67$ \\
N2 & $104.5 \mathrm{~b} \pm 2.62$ & $77.7 \mathrm{~d} \pm 2.65$ & $162.6 \mathrm{a} \pm 2.73$ \\
N3 & $68.6 \mathrm{~d} \pm 2.85$ & $80.5 \mathrm{bc} \pm 0.53$ & $98.1 \mathrm{~d} \pm 2.76$ \\
N4 & $183.1 \mathrm{a} \pm 4.74$ & $108.5 \mathrm{a} \pm 4.11$ & $160.9 \mathrm{a} \pm 9.33$ \\
P-value & 0.001 & 0.001 & 0.001 \\
\hline
\end{tabular}

$\pm \mathrm{SE}=$ standard error, $\mathrm{CW}, \mathrm{mH}, \mathrm{H}, \mathrm{WB}, \mathrm{ZB}=$ fresh $\mathrm{CPZ}$ extracts, $\mathrm{CW} 1, \mathrm{mH} 1, \mathrm{H} 1, \mathrm{WB} 1, \mathrm{ZB} 1=$ cultured.

System N4 recorded the highest $(\mathrm{P}<0.05)$ xylanase activity while N2, H1 and ZB1 were intermediate. Xylanase specific activities were much lower in the fresh systems than in the rest of the cultured systems. 


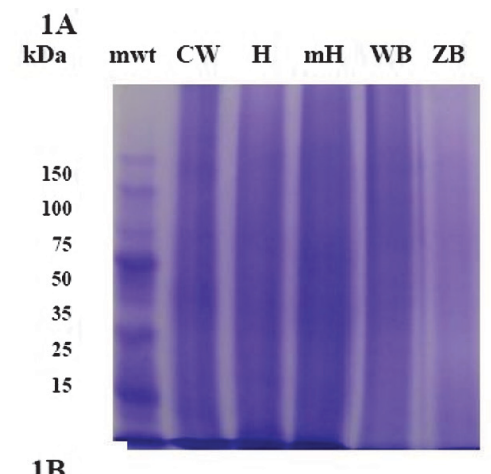

1D

kDa Mwt CW mH H WB ZB

kDa mwt CW1 H1 mH1 WB1 ZB1

$1 E$

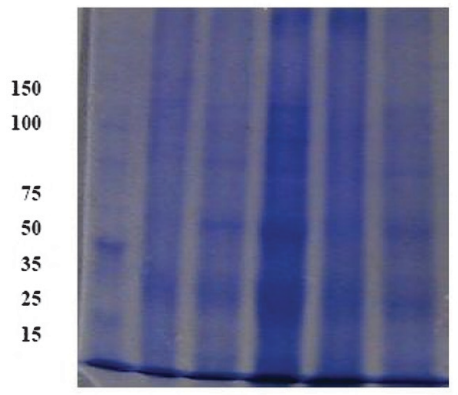

$\mathrm{kDa}$
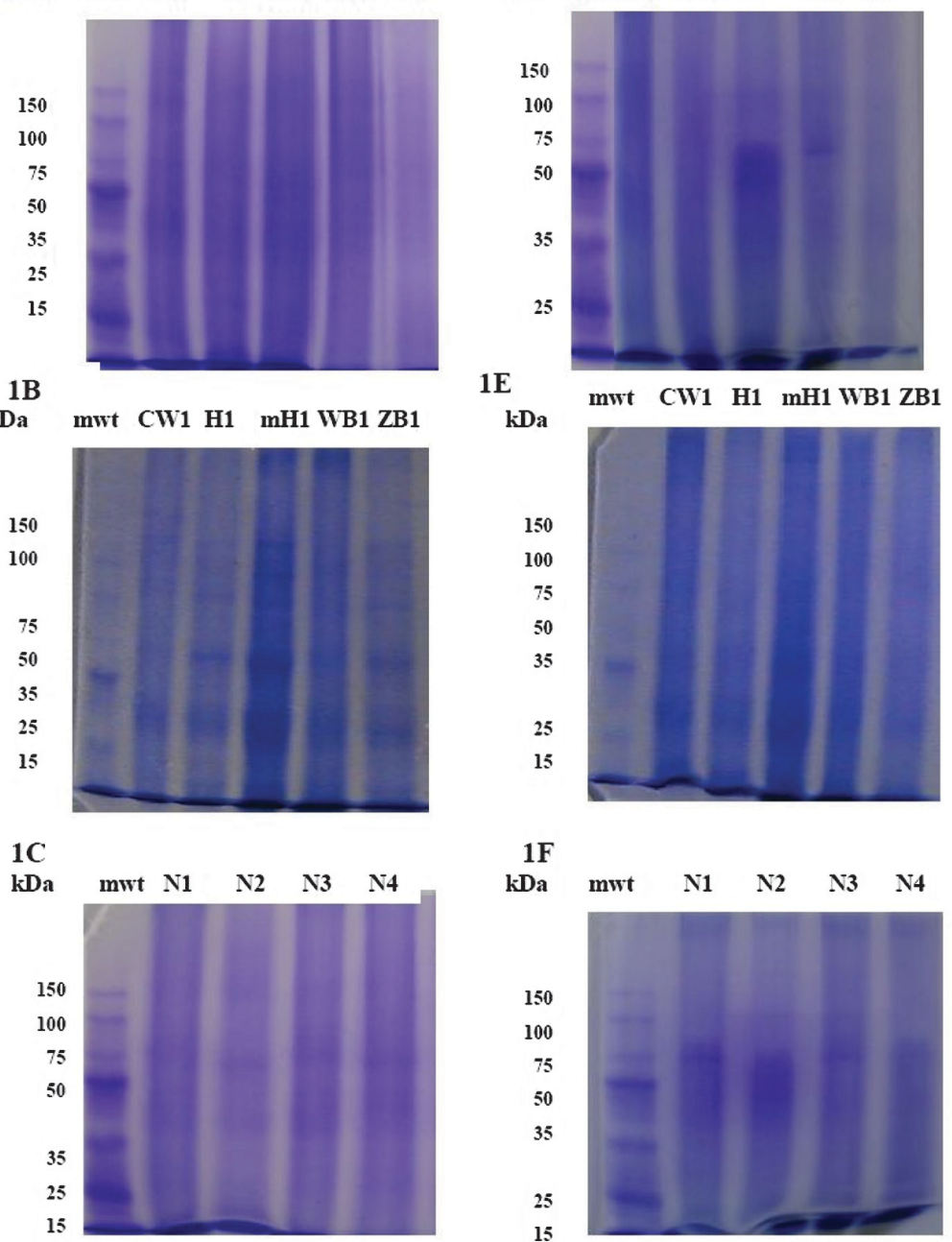

\section{$1 \mathrm{~F}$}

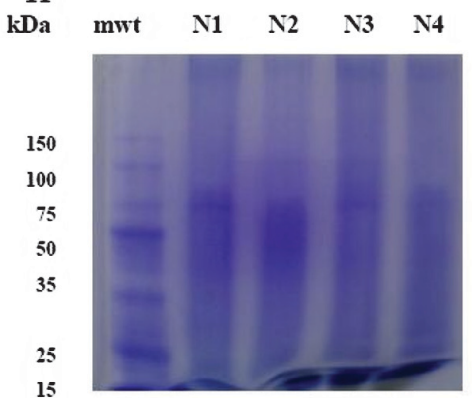

Figure 1. Coomassie stained Laemmli reducing and non-reducing 10\% SDS-PAGE monitoring the presence of proteins in crude protein extracts from different microbial ecosystems. $1 \mathrm{~A}, \mathrm{~B}$ and $\mathrm{C}$ are reducing SDS-PAGE while $\mathrm{D}, \mathrm{E}$ and $\mathrm{F}$ are non-reducing SDS-PAGE, mwt=molecular weight markers $(150,100,75,50,35,25$ and $15 \mathrm{kDa})$, fresh crude protein extract were from cow $(\mathrm{CW})$, horse $(\mathrm{H})$, miniature horse $(\mathrm{mH})$, wildebeest $(\mathrm{WB})$ and zebra $(\mathrm{ZB})$ while cultured crude protein extracts from CW1, H1, mH1, WB1, ZB1, N1 (H+WB), N2 (H+ ZB), N3 (WB+ZB) and N4 (H+WB+ZB)

SDS-PAGE demonstrated that all the CPZ extracts from the different microbial ecosystems contained proteins of diverse molecular weights. These CPZ contain numerous protein bands ranging from 1 to $250 \mathrm{kDa}$ (Figure $1 \mathrm{~A}, \mathrm{~B}, \mathrm{C}, \mathrm{D}, \mathrm{E}$ and $\mathrm{F}$ ). The thickness of protein bands from fresh CPZ was less than those observed after incubation. This was demonstrated by the prominent protein bands observed in fresh CPZ (Figure $1 \mathrm{~A}$ and D) compared to cultured CPZ (Figure 1 B, C, E and F). Specific 
protein abundance was variable in the different microbial cultures, Figure $1 \mathrm{C} \mathrm{(30,}$ 48, 50 and $91 \mathrm{kDa})$, Figure $1 \mathrm{~B}(30,40,50,70,75$ and $80 \mathrm{kDa})$, Figure $1 \mathrm{E}(30$ and 38 $\mathrm{kDa}$ ) and Figure $1 \mathrm{~F}$ (75 and $85 \mathrm{kDa})$. All nine CPZ extracted from in vitro microbial ecosystems exhibited endocellulase activities as demonstrated by the clear zones observed on zymograms (Figure 2). One major active band (216 kDa) was observed in all the CPZ from fresh systems (Figure $2 \mathrm{~A}$ ). Besides protein $216 \mathrm{kDa}$, the protein $180 \mathrm{kDa}$ also exhibited a higher endocellulase activity in WB and ZB. The active band $216 \mathrm{kDa}$ was common to all the cultured systems. The enzyme of $191 \mathrm{kDa}$ was present in all the combined systems (Figure $2 \mathrm{C}$ ) including H1 (Figure $2 \mathrm{~B}$ ). There were many other active bands on the gels that were too small to be captured by the photographic equipment available but were read and reported in Table 2. The total number of active protein bands varied among the nine microbial ecosystems. Cultured microbial ecosystems $\mathrm{CPZ}$ had more active cellulases than fresh $\mathrm{CPZ}$. In fresh $\mathrm{CPZ}$, the number of active endocellulases was 10, 7, 6, 5 and 5 for $\mathrm{ZB}, \mathrm{CW}, \mathrm{WB}, \mathrm{mH}$ and $\mathrm{H}$, respectively. In the cultured systems, the highest number of endocellulases was found in N1 (17), followed by N3, N4, and mH1 with 14, N2 and ZB1 having the least numbers.

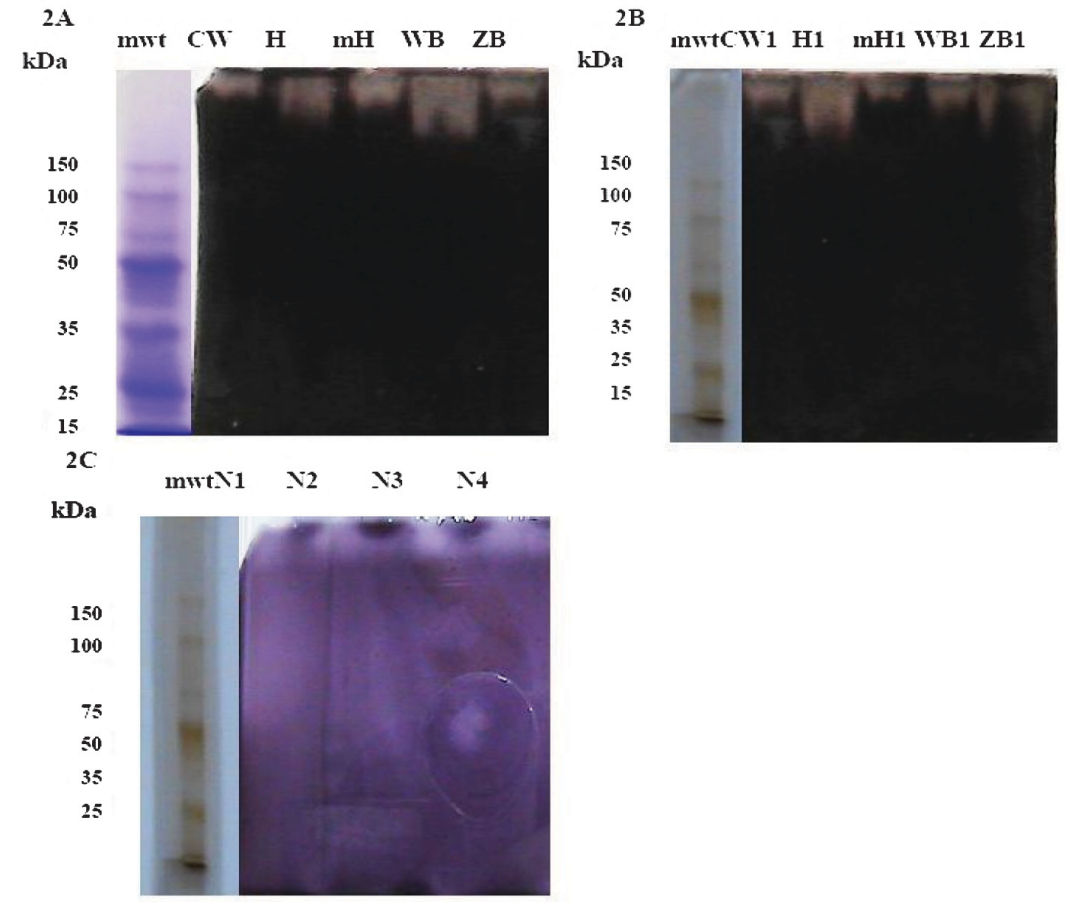

Figure 2. Zymograms of cellulase activities from crude protein extracts of nine in vitro microbial ecosystems on Laemmli non-reducing polyacrylamide gel electrophoresis. Endocellulases activities detected on non-reducing polyacrylamide gels containing 1\% CMC (2 A, B and C). The wells were loaded with crude protein samples $(10 \mu \mathrm{g} / 5 \mu \mathrm{l})$ extracted from both fresh $(\mathrm{CW}, \mathrm{H}, \mathrm{mH}, \mathrm{WB}$ and $\mathrm{ZB})$ and cultured (CW1, H1, mH1, WB1, ZB1, N1, N2, N3 and N4) microbial ecosystems and incubated for $48 \mathrm{~h}$ at $38^{\circ} \mathrm{C}$. Gels were stained with Congo red, rinsed with $5 \%$ acetic acid, mwt were stained with Coomassie-blue-250 or silver stain 


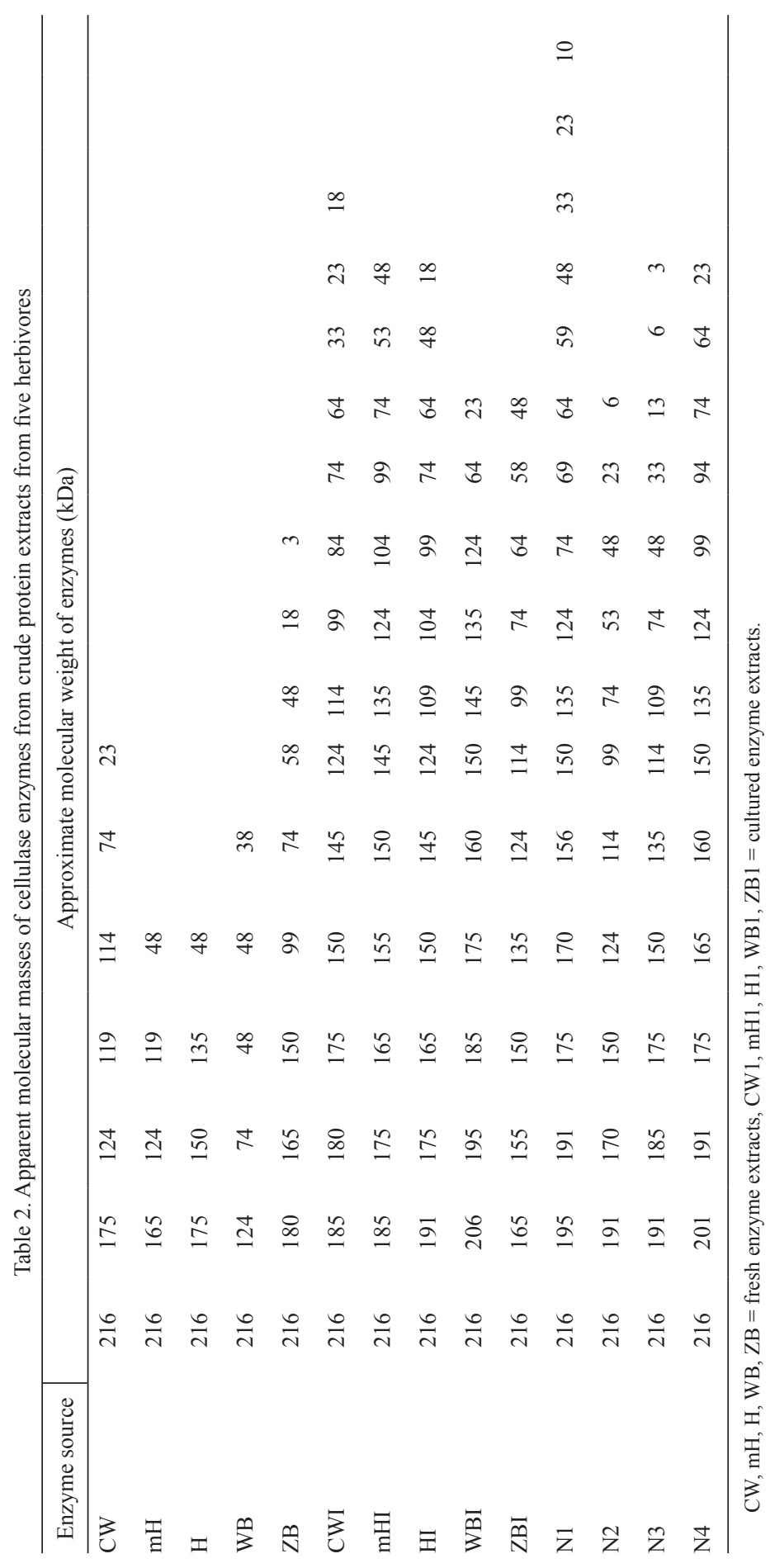




\section{Discussion}

This study was designed to investigate the presence and variation of cellulases in 5 in vitro herbivore microbial systems and their activeness in a consortium. All CPZ extracts were active as demonstrated by their exocellulase, endocellulase and xylanase activities when incubated with their specific substrates. Crude protein extract separation on both reducing and non-reducing SDS polyacrylamide gels was successful after staining with Coomassie blue G-250 but did not form prominent bands that could be captured by the camera at our disposal. The lack of prominent bands on the gels was due to low individual protein quantity since CPZ extracts contain numerous proteins and only a limited amount can be loaded on the gels at a time $(10 \mu \mathrm{g})$. Using a more sensitive method (Silver stain) to make these bands more visible failed as the whole gel turned black due to numerous protein bands (Oakley et al., 1980). However, the protein bands were more prominent for cultured CPZ than fresh. This was probably due to the absence of endogenous protein contamination (from the rumen or hindgut) in cultured systems than in fresh CPZ. Secondly, specific cellulase enzyme concentrations might have been enriched in cultured CPZ during culturing on maize stover and lucerne feed as the population of specific microbes increased. The lower number of endocellulases in fresh CPZ was probably due to smaller quantities of specific enzymes than their absence. Therefore, clear band formation on the gels might have been limited by smaller quantities of specific proteins on gels given the time of incubation. These results showed that where cellulase enzyme purification methods are limited, cultured CPZ extracts for enzyme assays and identification would be preferred to fresh CPZ.

The number and type of cellulases vary within and among herbivore species grazing on the same field. Seven of the protein bands with endocellulase activities were common in $\mathrm{CW}, \mathrm{H}$ and $\mathrm{mH}$ grazing on the same field while the remaining 13 cellulases were either present in one or two of the three animals. Five of the proteins $(216,150,124,99$ and $74 \mathrm{kDa})$ with endocellulase activities from herbivores in the wild were also found in the domesticated herbivores. The active protein bands 206, 195 and $58 \mathrm{kDa}$ were unique for herbivores in the wild. Though feed type does influence type of microbes and enzyme expression, its effect in this study was considered as minimal since all animals were being fed or grazing high fibre diets. Secondly, culturing with the same diet attempted to zero diet effect to enable enzyme potential to be the main dependent variable. Metagenomic studies of bovine rumen microflora by Ferrer et al. (2005) revealed nine active endo- $\beta$-1,4-glucanases less than observed in this study. This implies that crude method screening could be vital prior to enzyme purification and expression.

Clear bands on zymograms were evidence of CMC digestion as previously established by other researchers (Kim et al., 2009). Apart from N2, the total number of active proteins in N1, N3 and N4 were higher than those of its individual systems. This was associated to an increase in population of specific cellulase enzymes during culturing. The total number of active proteins ranked the systems as N1 $>$ N3 $>$ N4 $>$ N2. Although system N1 had the highest number of endocellulase (17), it was formed from individual systems with a combined number of 20 endocellulases. The differ- 
ent types of cellulase numbers observed in this study goes a long way to confirm the diversity of enzyme and microbes in the same or different microflora (Duan and Feng, 2010). Nine enzymes from the individual systems H1 and WB1 were absent in N1. There is likelihood that the expression of these missing enzymes might have been inhibited (proteolysis) by other microbes in the systems during recolonization of the different ecological niches (Morgavi et al., 2001). It is also possible that these enzymes might still be there but in smaller quantities (not detected on the gels) if not expressed by the dominant microbes in the niche.

The combined microbial ecosystems N1, N2, N3, and N4 were found with 5, 4, 5 and 2 new enzymes, respectively, which were not visible on the individual zymograms. These new enzymes may be coming from microbes which might have proliferated to become dominant in the new system conditions that was probably lacking in the previous individual ecological system. It is also possible to suggest that these enzymes (from variable microbial population) might have been there but in smaller quantities unable to form clear bands on the zymograms given the incubation time.

The molecular weights of proteins with CMCase activities in this study were browsed online (UniProtKB/Swiss-Prot, 2013) to verify their presence on protein databases. Almost all the bands were matched with cellulases of the same or similar molecular weights with protein names as cellulases or endoglucanase or endocellulase. These matching proteins were mainly from ruminant or hindgut microbes. Some of the active bands ( 3 and $6 \mathrm{kDa})$ were not found online from rumen or hindgut microbes but were available from other sources (Bronnenmeier et al., 1997; Clarke et al., 1997). Therefore, more research is required to establish these bands as novel. The molecular weight of cellulases isolated from rumen or hindgut microbes ranges from 9 to $160 \mathrm{kDa}$ online. The bands with higher molecular weights were suggested to be cellulosomes (complexes of cellulolytic enzymes). This was confirmed after browsing online and identifying cellulosomes with similar molecular weight (Najmudin et al., 2006). However, some cellulosomes were found with molecular weights lower than $150 \mathrm{kDa}$ (Gal et al., 1997). With the results obtained from zymography, it is possible to conclude that all the proteins that formed clear bands on the zymogram had endocellulase activities but it cannot be concluded that each clear band was a CMCase or cellulosome enzyme.

In conclusion, this study shows that all seven in vitro microbial ecosystems were active as demonstrated by their cellulase activities. Cellulases activities on zymograms are better studied with cultured than fresh inocula as culturing increases specific protein concentration. Cellulase expressions vary within and among animal species grazing on the same field. Endocellulases were higher in $\mathrm{CW}$ than $\mathrm{mH}$ and $\mathrm{H}$ grazing on the same field. Wildebeest and $\mathrm{ZB}$ varied with the types of endocellulases expressed but not in numbers. Transinoculation may be possible as indicated by the activeness of microbial consortia. The combined systems were ranked according to the number of cellulases they retained as $\mathrm{N} 1>\mathrm{N} 3>\mathrm{N} 4>\mathrm{N} 2$. Although four active bands $(206,216,6$ and $3 \mathrm{kDa})$ seem to be novel, more research is still required for its purification and characterization which could be used as feed additives. 


\section{Acknowledgement}

We would like to acknowledge the National Research Foundation for funding this project and the University of Zululand and University KwaZulu-Natal for facilitating the project.

\section{References}

A rriola K.G., Kim S.C., S taples C.R., A d e s og a n A.T. (2011). Effect of fibrolytic enzyme application to low- and high-concentrate diets on the performance of lactating dairy cattle. J. Dairy Sci., 94: 832-841.

B a la P., M a lik R., S r in i v a s B. (2009). Effect of fortifying concentrate supplement with fibrolytic enzymes on nutrient utilization, milk yield and composition in lactating goats. Anim. Sci. J., 80: 265-272.

B e a u chemin K.A., Colombat to D., Morgavi D.P., Yang W.Z. (2003). Use of exogenous fibrolytic enzymes to improve feed utilization by ruminants. J. Anim Sci., 81: 37-47.

B e g u in P. (1983). Detection of cellulase activity in polyacrylamide gels using congo red-stained agar replicas. Anal. Biochem., 131: 333-336.

B h a t M.K. (2000). Cellulases and related enzymes in biotechnology. Biotechnol. Adv., 18: 355-383.

B 1 u m H., B e i e r H., G r o s s H.J. (1987). Improved silver staining of plant-proteins, RNA and DNA in polyacrylamide gels. Electrophoresis, 8: 93-99.

B ronnenme i e r K., Kundt K., Ri ed e 1 K., S chwar z W.H., S ta u d e n b a u e r W.L. (1997). Structure of the Clostridium stercorarium gene celY encoding the exo-1,4-beta-glucanase Avicelase II. Microbiology, 143: 891-898.

C l a r k e A.J., D r u m m e $1 \mathrm{~s} \mathrm{~m}$ it h J., Ya g u ch i M. (1997). Identification of the catalytic nucleophile in the cellulase from Schizophyllum commune and assignment of the enzyme to Family 5, subtype 5 of the glycosidases. FEBS Lett., 414: 359-361.

Colo m b at to K.A., B e a u ch e m in D. (2003). A proposed methodology to standardize the determination of enzymic activities present in enzyme additives used in ruminant diets. Can. J. Anim. Sci., 83: 559-568.

Dodi a M.S., Rawal C.M., Bhimani H.G., Joshi R.H., Khare S.K., Singh S.P. (2008). Purification and stability characteristics of an alkaline serine protease from a newly isolated Haloalkaliphilic bacterium sp AH-6. J. Ind. Microbiol. Biotechnol., 35: 121-131.

D u a n C.J., F e n g J.X. (2010). Mining metagenomes for novel cellulase genes. Biotechnol. Lett., 32: $1765-1775$.

Ferrer M., Golyshina O.V., Chernikova T.N., Khachane A.N., Reyes-Duarte D., Dos Santos V., S trompl C., Elborough K., Jarvis G., N e ef A., Yakimov M.M., T i m m i s K.N., G o ly s h in P.N. (2005). Novel hydrolase diversity retrieved from a metagenome library of bovine rumen microflora. Environ. Microbiol., 7: 1996-2010.

G a 1 L., P a g e s S., G a u din C., B e 1 a i c h A., R e v e r b e 1 - L e r o y C., Ta r d if C., B e 1 a i c h J.P. (1997). Characterization of the cellulolytic complex (cellulosome) produced by Clostridium cellulolyticum. Appl. Environ. Microbiol., 63: 903-909.

Hall J., Ali S., Surani M.A., Hazelwood G.P., Clark A.J., Simons J.P., Hirst B.H., G i l b e r t H.J. (1993). Manipulation of the repertoire of oligestive enzymes secreted into the gastrointestinal tract of transgenic mice. Nat. Biotechnol., 11: 376-379.

H e u s s e n C., D ow d l e E.B. (1980). Electrophoretic analysis of plasminogen activators in polyacrylamide gels containing sodium dodecyl sulfate and copolymerized substrates. Anal. Biochem., 102: 196-202.

K i m D., B a i k K., P ark S., K i m S.-J., Sh in T.-S., J un g S.-J., O h M.-J., S e on g C. (2009). Cellulase production from Pseudoalteromonas sp. NO3 isolated from the sea squirt Halocynthia rorentzi. J. Ind. Microbiol. Biotechnol., 36: 1375-1382.

L a e m m li U.K. (1970). Cleavage of structural proteins during the assembly of the head of bacteriophage T4. Nature (London), 227: 680-685. 
Mille r G.L. (1959). Use of dinitrosalicylic acid reagent for determination of reducing sugar. Anal. Chem., 31: 426-428.

Morgavi D., Beauchemin K., Nsereko V., Rode L., McAllister T., Iwa asa A., Wang Y., Yang W. (2001). Resistance of feed enzymes to proteolytic inactivation by rumen microorganisms and gastrointestinal proteases. J. Anim Sci., 79: 1621-1630.

Najmudin S., Guerreiro C.I.P.D., Carvalho A.L., Prates J.A.M., Correia M.A.S., A lves V.D., Ferreira L.M.A., Romão M.J., Gilbert H.J., Bolam D.N., Fonte s C.M.G.A. (2006). Xyloglucan is recognized by carbohydrate-binding modules that interact with beta-glucan chains. J. Biol. Chem., 281: 8815-8828.

O ' Con nor-R ob i s on C.I., N i el s e n B.D., Morris R. (2007). Cellulase supplementation does not improve the digestibility of a high-forage diet in horses. J. Equine Vet. Sci., 27: 535-538.

O a kle y B.R., Kirsch D.R., M or r is N.R. (1980). A simplified ultrasensitive silver stain for detecting proteins in polyacrylamide gels. Anal. Biochem., 105: 361-363.

Percival Zhang Y.H., Himmel M.E., Mielenz J.R. (2006). Outlook for cellulase improvement: Screening and selection strategies. Biotechnol. Adv., 24: 452-481.

Peters A., Lebzien P., Meyer U., Borchert U., Bulang M., Flachowsky G. (2010). Effect of exogenous fibrolytic enzymes on ruminal fermentation and nutrient digestion in dairy cows. Arch. Anim. Nutr., 64: 221-237.

Till e y J.M.A., Te r r y R.A. (1963). A two-stage technique for the in vitro digestion of forage crops. J. Br. Grassl. Soc., 18: 104-111.

T it i H.H., T a b b a a M.J. (2004). Efficacy of exogenous cellulase on digestibility in lambs and growth of dairy calves. Livest. Prod. Sci., 87: 207-214.

Yang H.J., X i e C.Y. (2010). Assessment of fibrolytic activities of 18 commercial enzyme products and their abilities to degrade the cell wall fraction of corn stalks in in vitro enzymatic and ruminal batch cultures. Anim. Feed Sci. Technol., 159: 110-121.

Received: 6 VI 2013

Accepted: 8 X 2013 